\title{
Does Having Knowledge About Collateral Circulation Affect Patient Selection in Mechanical Thrombectomy?
}

\author{
Kollateral Dolaşım Hakkında Bilgi Sahibi Olmak Mekanik Trombektomide Hasta \\ Seçimini Etkiler mi?
}

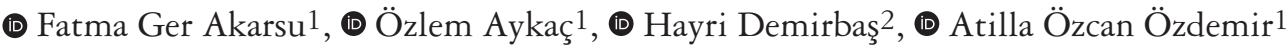 \\ 1Eskisehir Osmangazi University Faculty of Medicine, Department of Neurology, Eskisehir, Turkey \\ 2Afyon Kocatepe University Faculty of Medicine, Department of Neurology, Afyon, Turkey
}

\begin{abstract}
Endovascular thrombectomy is a well-known effective treatment in the first six hours of acute ischemic stroke, but endovascular therapy is also efficient in patients admitted six hours after symptom onset. The RAPID software is a powerful tool that processes computed tomography perfusion data and predicts ischemic core size and collateral status for endovascular treatment in these patients. Presented herein is a 66-year-old female patient with acute right middle cerebral artery occlusion with a symptom onset of $>6 \mathrm{~h}$. The reason why mechanical thrombectomy was not performed despite volume loss in the patient's perfusion imaging is also discussed. Brain hemodynamics is undeniably different in every patient, and this should be kept in mind while evaluating imaging methods based on blood flow, such as the RAPID software. Therefore, this report aimed to present a patient that demonstrated the importance of patient-based selection in acute ischemic stroke treatment.
\end{abstract}

Keywords: Acute stroke, mechanical thrombectomy, collateral circulation, RAPID perfusion

$\ddot{\mathbf{O} z}$

Akut inmede ilk altı saat içinde endovasküler tedavinin faydalı olduğu bilinmektedir, ancak yakın dönemde semptom başlama zamanından altı saat sonra görülen hastalarda da endovasküler tedavinin etkin olduğu gösterilmiştir. Bu hastalarda RAPİD yazılımı, bilgisayarlı tomografi perfüzyon verilerinin işlendiği ve endovasküler tedavi için iskemik korun büyüklüğünü ve kollateral durumu tahmin etmek için kullanılan güçlü bir tetkiktir. Burada, semptom başlangıç zamanı altı saatin üzerinde olan akut sağ orta serebral arter oklüzyonu ile başvuran altmış altı yaşında bir kadın hasta sunulmaktadır. Hastanın perfüzyon görüntülemesinde volüm kaybı olmamasına rağmen mekanik trombektomi uygulanmaması, sebepleri ile tartışılmıştır. Beyin hemodinamisinin her hastada farklı olduğu gerçeği RAPİD gibi kan akımı temeli üzerine oluşturulan görüntüleme yöntemlerini değerlendirmede göz ardı edilemez bir gerçektir. Bu nedenle, akut iskemik inmenin tedavisinde hasta temelli seçimin önemini gösteren bir hastamızı sunmak istedik.

Anahtar Kelimeler: Akut inme, mekanik trombektomi, kollateral dolaşım, RAPID perfüzyon

\section{Introduction}

Randomized controlled trials revealed that endovascular therapy is beneficial within the first $6 \mathrm{~h}$ after symptom onset in anterior system strokes with major vessel occlusion (1). Endovascular therapy was proven effective in patients with wake up stroke, with an unknown symptom onset time, or in patients seen $6 \mathrm{~h}$ after the last time with DAWN (DWI or CTP assessment with clinical mismatch in the triage of wake-up and late presenting strokes undergoing neurointervention with trevo) and DEFUSE-3 (endovascular therapy following imaging evaluation for ischemic stroke) studies published in 2018 (2). Computed tomography (CT) or magnetic resonance imaging-based software (RAPID software, iSchemaView, Menlo Park, CA, USA) was used in both studies, and the effect of suitable patient selection on treatment success was emphasized.

RAPID software is a program in which CT perfusion data are processed and presented for the reader's comment and is used to estimate the size of the ischemic core in patient selection for acute

Address for Correspondence/Yazışma Adresi: Fatma Ger Akarsu MD, Eskisehir Osmangazi University Faculty of Medicine, Department of Neurology, Eskisehir, Turkey

Phone: +90 5058905108 E-mail: fatma.ger@hotmail.com ORCID: orcid.org/0000-0003-3171-4535

Received/Geliş Tarihi: 04.09.2020 Accepted/Kabul Tarihi: 19.02.2021

${ }^{\circ}$ Copyright 2021 by Turkish Neurological Society

Turkish Journal of Neurology published by Galenos Publishing House. 
ischemic stroke endovascular treatment $(3,4,5)$. The ischemic core represents infarcted tissue without potential recovery even if complete reperfusion is achieved. True ischemic core estimation by evaluating perfusion parameters is a powerful predictor for the development and clinical outcomes of parenchymal hematomas (6). Patients with small ischemic cores but large penumbra area or severe clinical manifestations are candidates for endovascular therapy $(7,8)$.

With the RAPID software, four basic parameters that reveal the hemodynamics of the brain are examined. One of these parameters is the cerebral blood flow (CBF), the value (in milliliters) of blood reaching $100 \mathrm{~g}$ of brain tissue per minute. It is $50 \mathrm{ml} / 100 \mathrm{~g} / \mathrm{min}$ for brain tissue with a normal blood supply. Cerebral blood volume $(\mathrm{CBV})$ is the blood volume in $100 \mathrm{~g}$ brain tissue; this volume is $5 \mathrm{ml} / 100 \mathrm{~g}$ for healthy brain tissue. Mean transit time (MTT) is the transition time of blood reaching the brain tissue from the arterial phase to the venous phase. Time to peak (TTP) is the time interval between the first arrival of contrast intracranially and the amount of contrast reaches the measured peak concentration in seconds $(9,10)$. Three parameters are formulated as $\mathrm{CBF}=\mathrm{CBV} /$ MTT (11). In the ischemic core in acute ischemia, CBV and CBF decreased, whereas MTT and TTP increased. In the penumbra, which is a recoverable tissue, preserved CBV due to autoregulation, slightly decreased CBF, and increased MTT and TTP are seen $(12,13,14)$. Despite all these standardized parameters, our ability to identify core, penumbra, and benign oligemia using blood flow measurements is affected by conceptual and technical flaws (13). According to the DEFUSE-3 study, the target mismatch criteria of RAPID are core volume of $<70 \mathrm{ml}$, mismatch ratio of $\geq 1.8$, and mismatch volume of $\geq 15 \mathrm{ml}$.

Collateral circulation is an important factor determining the growth rate of infarct tissue. Detailed information about collateral status is obtained by measuring relative $\mathrm{CBV}(\mathrm{rCBV})$ and hypoperfusion index (HIR) with RAPID software. Mean rCBV was obtained by dividing the average of all $\mathrm{CBV}$ values from the $\mathrm{T}_{\text {max }}>6 \mathrm{~s}$ region within the ischemic hemisphere by the average of all CBV values from all tissue with $\mathrm{T}_{\max } \leq 4 \mathrm{~s}$. HIR was calculated as the quotient between the volumes with $\mathrm{T}_{\max }>10 \mathrm{~s}$ and $\mathrm{T}_{\max }>6 \mathrm{~s}$ (15).

The fact that brain hemodynamics is different in every patient is undeniable in evaluating imaging methods based on blood flow, such as the RAPID. Therefore, a patient that demonstrated the importance of patient-based selection in the treatment of acute ischemic stroke is presented.

\section{Case Report}

A 66-year-old female patient was referred to the Eskisehir Osmangazi University Stroke Center from the primary stroke unit 126 kilometers away due to left-sided weakness, speech impairment, and forced head-eye deviation. Blood pressure was $160 / 80 \mathrm{mmHg}$ and pulse rate was $98 \mathrm{bpm}$. In her neurological

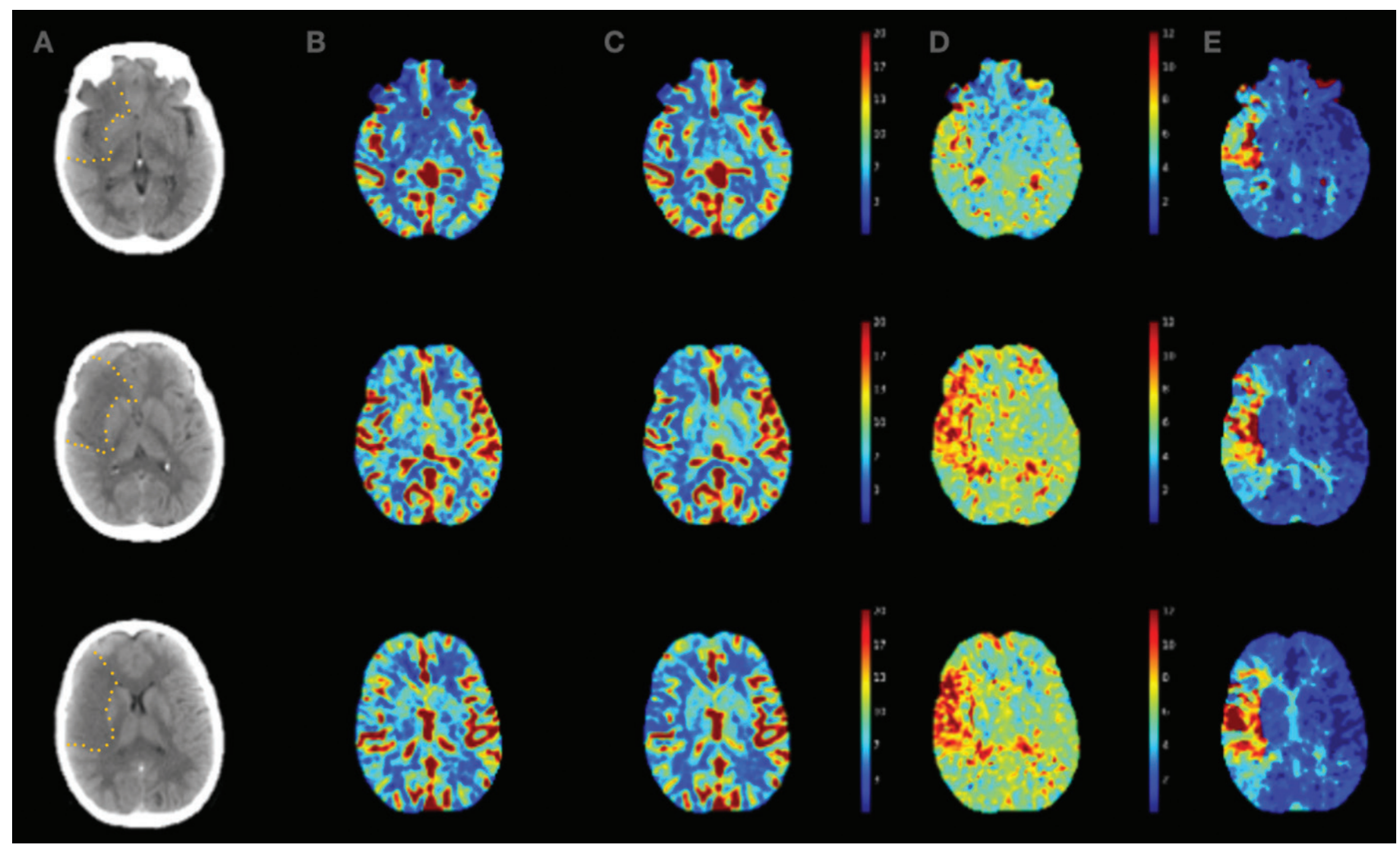

Figure 1. RAPID perfusion imaging and non-contrast brain computed tomography upon admission. (A) Hypodens area is framed by yellow dots and is compatible with subacute infarction in the territory of the middle cerebral artery. Incompatible with cerebral blood volume (B) and cerebral blood flow (C). The mean transit time (MTT) (D) and the time to reach the maximum blood flow $\left(\mathrm{T}_{\max }\right)(\mathrm{E})$ show delay in the area compatible with the infarct 
examination; The United States National Institute of Health Stroke Scale was 14. She was conscious, with normal orientation and cooperation and left homonymous hemianopia, left central facial paralysis and neglect phenomenon, left upper extremity muscle strength of $1 / 5$, and left lower extremity muscle strength of $2 / 5$. Her history revealed usage of $2 \times 5 \mathrm{mg} / \mathrm{d}$ apixaban due to mitral stenosis, but she had not taken the drug for the last week. Laboratory examinations revealed a hemoglobin value of $14.6 \mathrm{~g} /$ $\mathrm{dl}(12-17 \mathrm{~g} / \mathrm{dl})$ and blood glucose of $97 \mathrm{mg} / \mathrm{dl}(70-110 \mathrm{mg} / \mathrm{dl})$. The electrocardiogram showed a normal sinus rhythm. Alteplase treatment was initiated at the second hour of the symptom onset and she was sent to our comprehensive stroke center for mechanical thrombectomy due to the absence of clinical benefit. CT perfusion imaging was performed. When she reached our center, the symptom onset time was over $6 \mathrm{~h}$. Brain CT, CT angiography, and CT perfusion imaging (using RAPID software) were performed.

On unenhanced CT, a temporoparietal subacute infarct area involving the insular cortex was observed, but the basal ganglia were preserved. During admission, Alberta Stroke Program Early CT (ASPECT) score was 5 (Figure 1). Increased MTT and TTP were detected in RAPID software, without changes in CBF and CBV (Figure 1). On CT angiography, the right middle cerebral artery (MCA) was occluded in the distal part of the M1 segment. The collateral Tan scale score was $50-100 \%$ (Figure 2). The HIR rate $\left(\mathrm{T}_{\max }>10 / \mathrm{T}_{\max }>6\right)$ in the RAPID perfusion imaging of the patient was 0.3 (Figure 3), and the mismatch rate could not

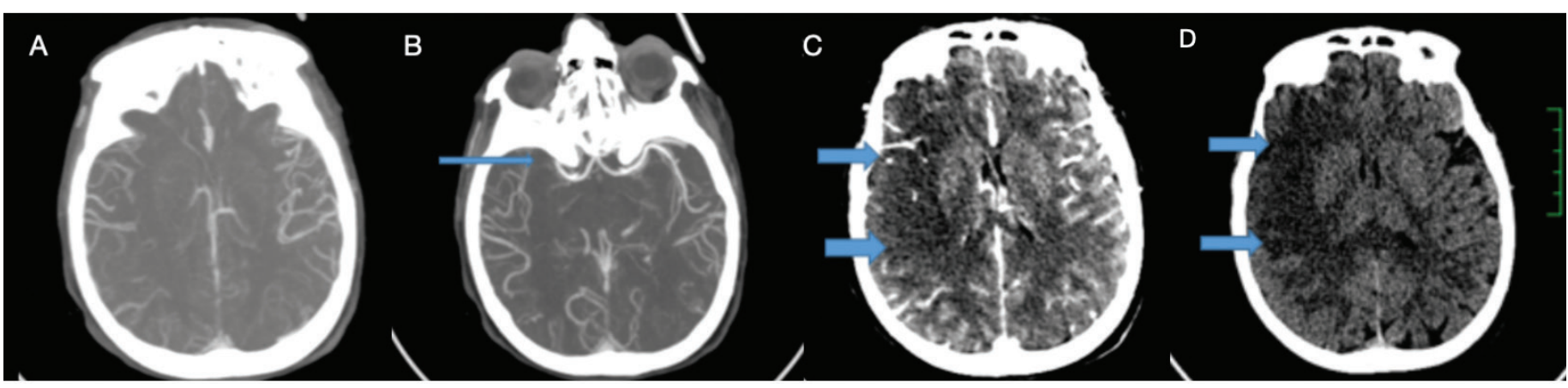

Figure 2. Collateral Tan scale score in the brain computed tomography angiography (CTA) images is 50-100\% (A). In CTA, the right MCA M1 segment is occluded (B, blue thin arrow). The demarcation line is visible in CTA source imaging (C, blue thick arrows). A 24-hour control brain CT shows the infarct area in the right MCA area consistent with the previous images (D, blue thick arrows)

MCA: Middle cerebral artery

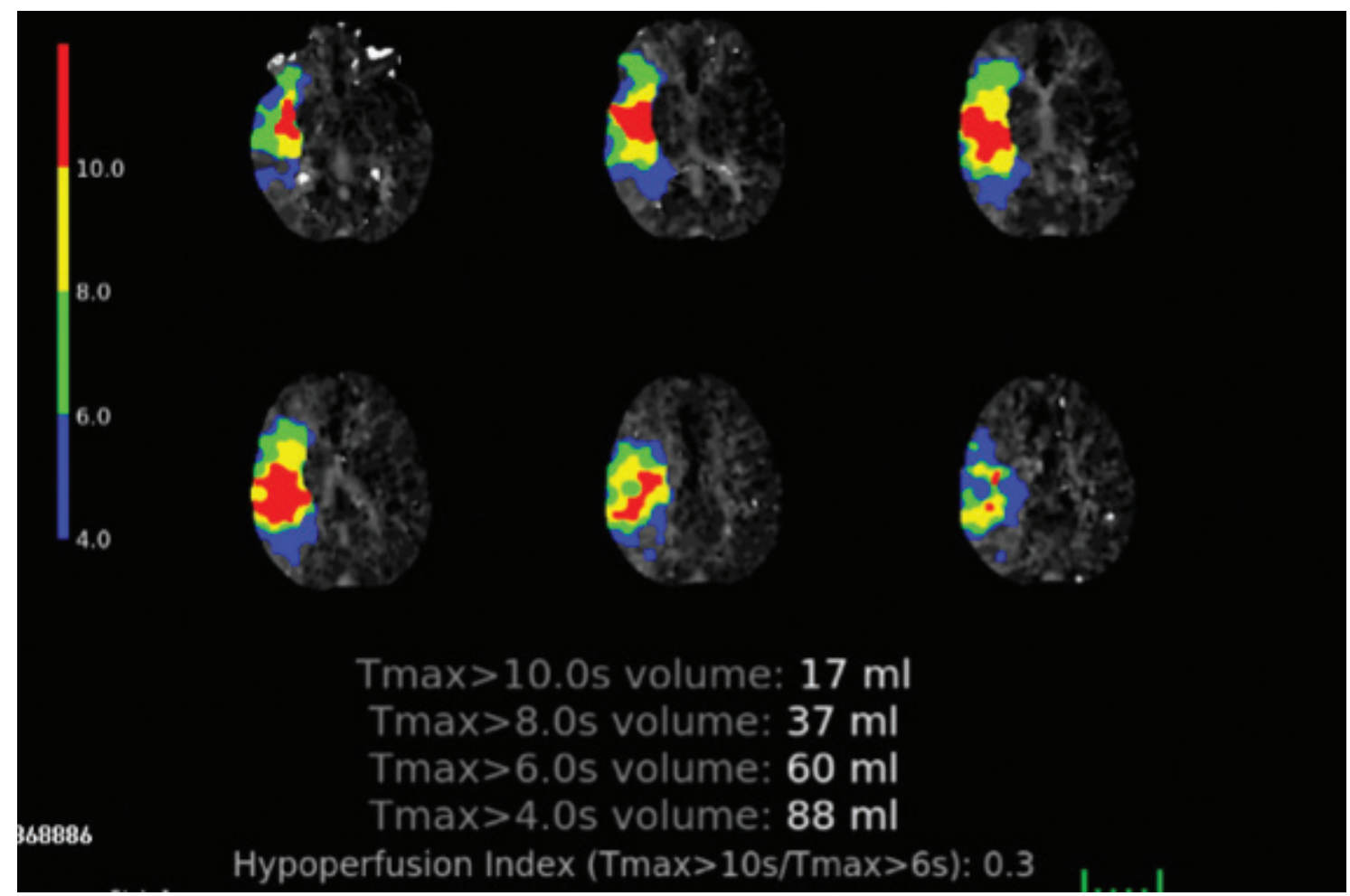

Figure 3. The hypoperfusion index ratio $\left(\mathrm{T}_{\max }>10 / \mathrm{T}_{\max }>6\right)$ in the RAPID perfusion imaging of the patient is 0.3 , showing good collateral circulation 


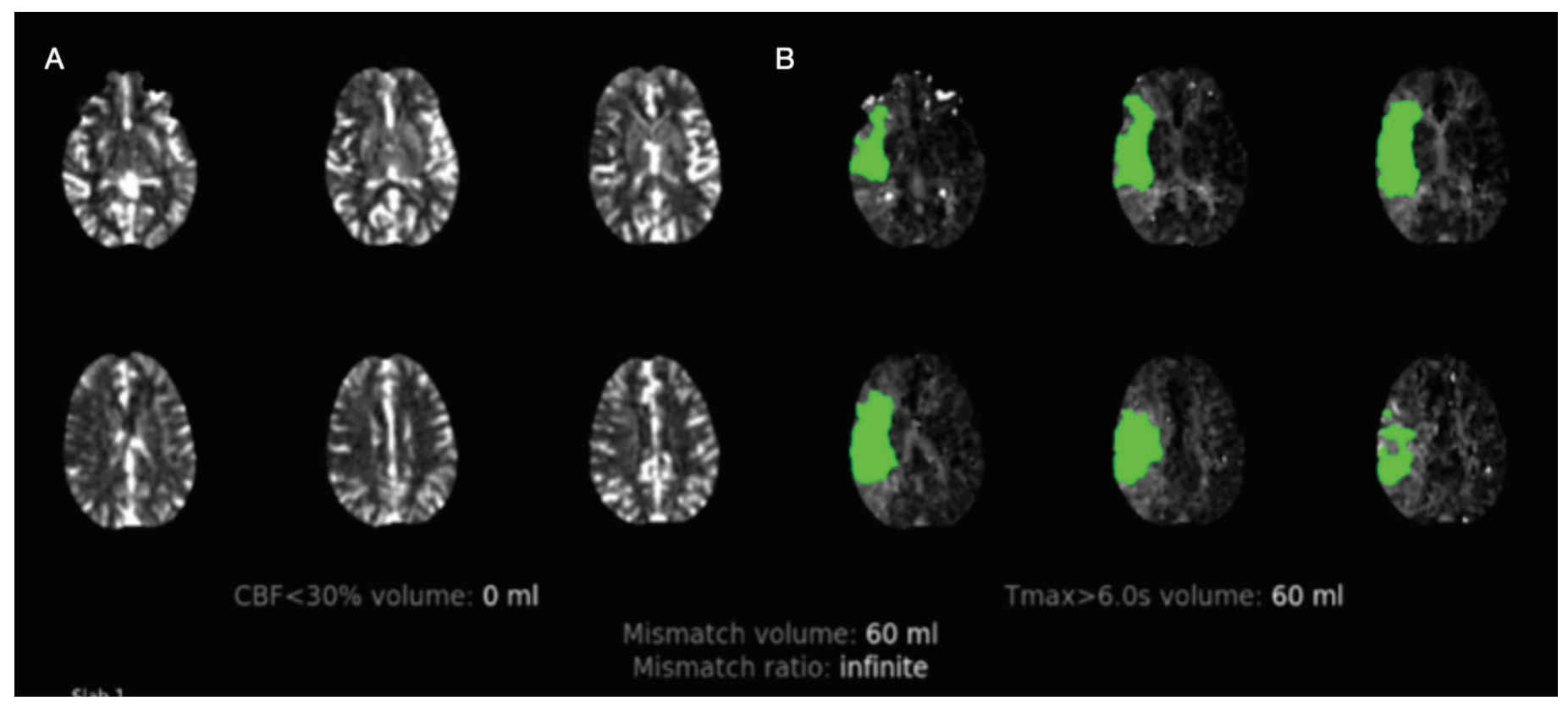

Figure 4. Since there was no blood flow change in the CBF sequence in the RAPID perfusion mismatch map (A, B) of the patient, the mismatch rate was not determined

CBF: Cerebral blood flow

be calculated due to the blood flow change absence in the CBF sequence in the perfusion mismatch map (Figure 4). Ischemic core was not observed in RAPID software; however, endovascular treatment was not performed due to low CT and contrast CT ASPECT scores. In the neurological examination performed $24 \mathrm{~h}$ later, the left upper extremity was 3-4/5 and the lower extremity was $4 / 5$. In the control brain CT, the infarct area was observed in the same area as observed in the admission CT (Figure 2). Informed consent was obtained from the patient.

\section{Discussion}

Neuroimaging performed to determine reperfusion therapies of patients with acute ischemic stroke with major vessel occlusion should be evaluated considering all factors such as the patient's clinical status, symptom onset time, and cerebral collateral circulation. RAPID software, which is widely used to reveal recoverable brain tissue in late-presenting patients and in patients with an unknown symptom onset time is affected by the patient's current cardiac reserve; extracranial/proximal intracranial carotid stenosis; factors that alter the time of contrast to reach the intracranial circulation, such as cerebrovascular steal syndromes; and blood flow parameters such as collateral circulation $(16,17)$.

In the non-contrast CT, an infarct area was observed in an anatomical location compatible with the current clinical findings in our patient. Infarct tissue was also observed in brain CT angiography source images, and the collateral Tan scale score of the hemisphere with MCA occlusion was $>50 \%$. The RAPID software was observed to not detect the infarct volume due to her good collateral circulation.

Prolonged delays in $\mathrm{T}_{\max }$ were associated with poor collateral circulation. Regions with a delay in $\mathrm{T}_{\max }$ of $>10 \mathrm{~s}$ are known to be associated with weak collateral reserve (18). The SWIFT PRIME study concluded that in addition to the low HIR rate in CTP, higher mean CBV in hypoperfused areas is an indicator of good collateral circulation (19). HIR ( $\left.\mathrm{T}_{\max }>10 / \mathrm{T}_{\max }>6\right)$ of $>50 \%$ indicated poor collateral circulation, which was 0.3 in our patient, with RAPID perfusion of good collateral circulation in line with the Tan scale score (Figure 3).

Another situation that would hide acute or subacute infarction is the reperfusion phenomenon. However, in this case, a decreased MTT and increased CBF and CBV were observed (20). The reperfusion phenomenon with the current RAPID results of our patient was excluded.

The treatment plan and management are tried to fit within the framework of certain algorithms; however, the treatment strategy for acute ischemic stroke should be considered in each patient. As in our patient, evaluating the clinical findings and all imaging data with a semiological approach in a holistic manner and making a decision prevents unnecessary procedures and possible complications for the patient.

\section{Ethics}

Informed Consent: Patient consent was obtained.

Peer-review: Externally peer-reviewed.

\section{Authorship Contributions}

Surgical and Medical Practices: F.G.A., Ö.A., H.D., A.Ö.Ö., Concept: F.G.A., Ö.A., H.D., A.Ö.Ö., Design: F.G.A., Ö.A., H.D., A.Ö.Ö., Data Collection or Processing: F.G.A., Ö.A., H.D., A.Ö.Ö., Analysis or Interpretation: F.G.A., Ö.A., H.D., A.Ö.Ö., Literature Search: .G.A., Ö.A., H.D., A.Ö.Ö., Writing: F.G.A., Ö.A., H.D., A.Ö.Ö. 
Conflict of Interest: No conflict of interest was declared by the authors.

Financial Disclosure: The authors declared that this study received no financial support.

\section{References}

1. Goyal M, Demchuk AM, Menon BK, et al; ESCAPE Trial Investigators. Randomized assessment of rapid endovascular treatment of ischemic stroke. N Engl J Med 2015;372:1019-1030.

2. Albers GW, Marks MP, Kemp S, et al; DEFUSE 3 Investigators. Thrombectomy for stroke at 6 to 16 hours with selection by perfusion imaging. N Engl J Med 2018;378:708-718.

3. El-Koussy M, Schroth G, Brekenfeld C, Arnold M. Imaging of acute ischemic stroke. Eur Neurol 2014;72:309-316.

4. Yew KS, Cheng EM. Diagnosis of acute stroke. Am Fam Physician 2015;91:528-536

5. Kamalian S, Lev MH. Stroke imaging. Radiol Clin North Am 2019;57:717732.

6. Mokin M, Levy EI, Saver JL, et al; SWIFT PRIME Investigators. Predictive value of RAPID assessed perfusion thresholds on final infarct volume in SWIFT PRIME (solitaire with the intention for thrombectomy as primary endovascular treatment). Stroke 2017;48:932-938.

7. Albers GW, Lansberg MG, Kemp S, et al. A multicenter randomized controlled trial of endovascular therapy following imaging evaluation for ischemic stroke (DEFUSE 3). Int J Stroke 2017;12:896-905.

8. Nogueira RG, Jadhav AP, Haussen DC, et al; DAWN Trial Investigators Thrombectomy 6 to 24 hours after stroke with a mismatch between deficit and infarct. N Engl J Med 2018;378:11-21.

9. Murphy BD, Fox AJ, Lee DH, et al. Identification of penumbra and infarct in acute ischemic stroke using computed tomography perfusion-derived blood flow and blood volume measurements. Stroke 2006;37:1771-1777.
10. Kan PT, Snyder KV, Yashar P, et al. Utility of CT perfusion scanning in patient selection for acute stroke intervention: experience at University at Buffalo Neurosurgery-Millard Fillmore Gates Circle Hospital. Neurosurg Focus 2011;30:E4.

11. Hoeffner EG, Case I, Jain R, et al. Cerebral perfusion CT: technique and clinical applications. Radiology 2004;231:632-644.

12. Allmendinger AM, Tang ER, Lui YW, Spektor V. Imaging of stroke: Part 1, Perfusion CT--overview of imaging technique, interpretation pearls, and common pitfalls. AJR Am J Roentgenol 2012;198:52-62.

13. Goyal M, Menon BK, Derdeyn CP. Perfusion imaging in acute ischemic stroke: let us improve the science before changing clinical practice. Radiology 2013;266:16-21.

14. Kilburg C, Scott McNally J, de Havenon A, et al. Advanced imaging in acute ischemic stroke. Neurosurg Focus 2017;42:E10.

15. Arenillas JF, Cortijo E, García-Bermejo P, et al. Relative cerebral blood volume is associated with collateral status and infarct growth in stroke patients in SWIFT PRIME. J Cereb Blood Flow Metab 2018;38:1839-47.

16. Huang BY, Castillo M. Radiological reasoning: extracranial causes of unilateral decreased brain perfusion. AJR Am J Roentgenol 2007;189(Suppl 6):S49-S54.

17. Lui YW, Tang ER, Allmendinger AM, Spektor V. Evaluation of CT perfusion in the setting of cerebral ischemia: patterns and pitfalls. AJNR Am J Neuroradiol 2010;31:1552-1563.

18. Albers GW. Use of imaging to select patients for late window endovascular therapy. Stroke 2018;49:2256-2260.

19. Ravindran AV, Killingsworth MC, Bhaskar S. Cerebral collaterals in acute ischaemia: Implications for acute ischaemic stroke patients receiving reperfusion therapy. Eur J Neurosci 2021;53:1238-1261.

20. Kuner AD, Rowley HA. Should perfusion CT and cta be performed in all patients with suspected stroke? Point-yes, for fast and accurate stroke triage and treatment. AJR Am J Roentgenol 2021;217:291-292. 